\title{
Estimation of biological parameters for germination of Abutilon theophrasti Medik.
}

\author{
VALENTINA ŠOŠTARČIĆ ${ }^{1}$ \\ MAJA ŠĆEPANOVIĆ ${ }^{1}$ \\ ROBERTA MASIN ${ }^{2}$ \\ DARIO MAGOSSO ${ }^{2}$ \\ GIUSEPPE ZANIN ${ }^{2}$ \\ ${ }^{1}$ Sveučilište u Zagrebu, Agronomski fakultet, \\ Svetošimunska cesta 25, 10000 Zagreb \\ 2 University of Padova, Department of Agronomy, \\ Food, Natural Resources, \\ Animals and Environment (DAFNAE), Viale dell' \\ Università 16, 35020 Legnaro

\section{Correspondence:} \\ Valentina Šoštarčić \\ E-mail:vsostarcic@agr.hr
}

Key words: invasive weed species, velvetleaf, germination modelling, integrated weed management, base temperature, base water potential
Received March 14, 2017.

Revised March 02, 2019.

Accepted April 02, 2019.
Background and Purpose: Velvetleaf seed longevity and prolonged emergence complicate assessing appropriate time for its control. Estimating biological parameters (base temperature and base water potential) is a first step towards development of emergence predictive model for this weed species in summer crops. Since, development of new model is time consuming, the aim of the research was to provide the data set of biological thresholds for Croatian ecotype and then to compare it with Italian velvetleaf thresholds to assess the implementation of AlertInf predictive weed emergence model from Italy to Croatia.

Materials and methods: Laboratory experiments were conducted with 100 seeds per three replicates at seven constant temperatures $(4,8,12,16$, $\left.20,24,28^{\circ} \mathrm{C}\right)$ to estimate base temperature $\left(T_{b}\right)$ and at seven water stress levels $(0.00,-0.05,-0.10,-0.25,-0.38,-0.50,-0.80,-1.00 \mathrm{MPa})$ to estimate base water potential $\left(\Psi_{b}\right)$.

Results: Germination was fastest at temperature $>20^{\circ} \mathrm{C}$ with 3.6 days and at water stress level $>-0.25 \mathrm{MPa}$ with 4.9 days to complete $50 \%$ of germination $\left(t_{50}\right)$. The slowest $t_{50}$ occurred at $4^{\circ} \mathrm{C}(41.9$ days) and $<-0.38$ $\mathrm{MPa}$ (10.1 days). Estimated Croatian velvetleaf biological parameters are: $4.5^{\circ} \mathrm{C}\left(T_{b}\right)$ and $-0.67 \mathrm{MPa}\left(\Psi_{b}\right)$ with no significant difference compared to Italian ecotype, according to $95 \%$ confidence intervals overlapping.

Conclusion: The results indicate that it could be possible to implement AlertInf model from Italy to Croatia for this weed species without additional adjustment. Nevertheless, next step of this implementation should include validation of estimated results in the field conditions.

\section{INTRODUCTION}

$\mathrm{V}$ elvetleaf (Abutilon theophrasti Medik.) is an annual weed species common in corn, soybean and sugar beet fields. Its success to establish in row summer crops is mostly attributed to poor weed control by pre-emergence (PRE) herbicides (1). Escaped and then not controlled individuals usually produce high number of seed per plant, up to 44 200 (2) with high physical seed dormancy (3) which could have longterm consequences for weed management. Along with this, herbicide absorption could be enabled due to velvetleaf burial depth in the soil. Typically, PRE herbicides have a good efficacy on the seeds with low seed weight, capable to emerge from the shallow soil depths (4) in the herbicide application zone, but provide scarce control of seeds with higher seed weight such as velvetleaf with 1000 seed weight of $9.1 \mathrm{~g} \mathrm{(5).}$ Although, most of velvetleaf seeds emerge in the early period of vegetation season, its emergence can be prolonged during the midgrowing season as well (6) when applied herbicides are not efficient anymore.

Such insufficient control of PRE herbicide required a switch to a post-emergence (POST) application, today recognized as a part of In- 
tegrated Weed Management. This approach permits the selection of the most effective herbicide, or combination of herbicides, based on emerged weeds in the field (7). Despite all unquestionable benefits, efficacy of POST herbicides depends mostly on time and duration of weed emergence in the field (8). Thus the knowledge of weed emergence is crucial to assess the right time for weed control. It is usually suggested that farmers apply POST herbicides when approximately 70 to $80 \%$ of weeds had emerged (9). For example, with too early applications is very likely to have new flush of weed emergence. As consequence, herbicide application should be repeated, which is not environmentally safe and economically profitable. Otherwise, too late application can be less effective especially on weeds with morphological barriers such as waxes and hairs on leaf surface (10). Velvetleaf develops hairs on the leaf surface that slower herbicide absporbion. Therefore is recommended to apply herbicides at earliest growth stage (cotyledons) were is found out that absorption of triflusurfuron (common used herbicide in sugar beet) is about $28 \%$ better than applied at first true leave (11).

In order to provide information to farmers about right time for weed control, predictive weed emergence models are developed (12). The main goal of these models is to assess the time span in which most individuals in populations had emerge in the field. Currently, three types of predictive weed emergence models are developed: phenological, empirical and mechanistic (reductionist) models. Most used are empirical models based on monitoring weed emergence at precise field for several years with the intention to estimate their time of emergence in the future years. Often, empirical models combine calendar days of seedling appearance in the field with temperature requirements of each weed species. First generation of weed emergence models were based primary on thermal time (TT) concept $(13,14,15)$ where daily mean soil (eventually air) temperature is accumulated above a specific threshold (base temperature $-\mathrm{T}_{\mathrm{b}}$ ), during the cropping season until weed emergence is completed (16). Since temperature is not the only factor that influences germination and these models are not able to accurately predict seedling emergence in condition of water stress, second generation of predictive weed models are developed by integrating soil water potential and soil temperature into hydrothermal time (HTT) models. These models can be better at predicting emergence than TT models (17) as they include soil water availability, necessary for seed imbibition and germination (water potential $-\Psi_{\mathrm{b}}$ ). Biological parameters $\left(\mathrm{T}_{\mathrm{b}}\right.$ and $\left.\Psi_{\mathrm{b}}\right)$ are specific for each weed species, but also for different ecotype of species due to different growing and environmental area of development $(12,18,19,20)$.

AletInf is a weed emergence model developed for predicting emergence of some common summer weed species in maize and soybean fields in Veneto region. The model is based on HTT concept and it is available as an interac- tive web service on the web site of meteorological station ARPAV for farmers in the Veneto Region (http://www. arpa.veneto.it/upload_teolo/agrometeo/infestanti.htm). The information provided to farmers by AlertInf is the percentage of weeds that have already emerged in the field out of the total number of weeds that may potentially emerge until the end of season (12).

Currently in Croatia there are no developed predictive models. The idea of this study is to transfer AlertInf model from Italy to Croatia. Hypothesis is that for some weed species the same biological parameters could be used in different geographical areas, without conducting specific experiments that are time and sources consuming. Therefore the first step, before implementation of Alertinf in Croatia is estimation of biological parameters $\left(\mathrm{T}_{\mathrm{b}}\right.$ and $\left.\Psi_{\mathrm{b}}\right)$ for Croatian velvetleaf ecotype in order to compare them with Italian ecotypes for the same species. This comparison is necessary to verify the difference or similitude in germination-emergence behaviour of ecotypes of species simulated by AlertInf and therefore to evaluate the transferability of the model.

Velvetleaf was chosen to be the first weed species for estimation and comparison of biological thresholds. According to farmer reports, velvetleaf is often unsuccessfully controlled in sugar beet and soybean crops. Because of its seed longevity, high seed weight and prolonged emergence in the field, producers usually have problem with estimating appropriate time for a weed control. Therefore, development of predicting weed emergence model for this species would have practical and positive effect on its successful control in important summer crops. Therefore the objectives of this study were i) to provide data set of base temperatures and base water potential for weed species $A$. theophrasti and ii) to compare Italian and Croatian ecotype of velvetleaf with the intension to verify the possibility of introduction AlertInf predictive emergence model from Italy to Croatia using same biological parameters.

\section{MATERIALS AND METHODS}

Experiments to determinate base temperature were conducted at the University of Zagreb, Faculty of Agriculture, Department of Weed Science in 2012. Experiments to determinate base water potential were conducted at the University of Padova, Department of Agronomy, Food, Natural resources, Animals and Environment in 2014. Both experiments were performed at constant temperature in germination chamber equipped with UV lamps.

\section{Seed collection}

Seeds were collected from spontaneous population of velvetleaf in maize field in summer of 2011 at experimental station of Faculty of Agriculture, University of Za- 


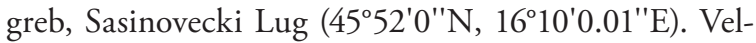
vetleaf mature capsules were collected and then seeds were gently hand cleaned and stored in dry conditions until experiment initiation. Before using the seeds in the experiment, seeds were mechanical scarificated with sandpaper (12) in order to break physical dormancy and enable seed imbibition.

\section{Base temperature for germination}

Base temperature experiment was composed of three replicates with 100 seeds per Petri dish. Seeds were placed on filter paper imbibed with $10 \mathrm{ml}$ of deionized water into 19-cm-diam Petri dishes sealed with parafilm. Petri dishes were then incubated in germination chambers at seven different constant temperatures $(4,8,12,16,20,24$, $28^{\circ} \mathrm{C}$ ) and photoperiods of 12:12 h (light: dark).

\section{Base water potential for germination}

Eight treatments were conducted to determine the effect of osmotic stress on germination. Polyethylene glycol (PEG) 6000 (Sigma-Aldrich Chemie GmbH 25322-683 ) was used to prepare solutions with eight water stress levels: $0.00,-0.05,-0.10,-0.25,-0.38,-0.50,-0.80$, $-1.00 \mathrm{MPa}$. Treatments with polyethylene glycol solution consisted of three replicates of 100 seeds per each transparent plastic containers $10-\mathrm{cm}$-diam, $7-\mathrm{cm}$-high as described by Masin et al. (12) Containers with $50 \mathrm{ml}$ of prepared solution were placed at a constant temperature of $22^{\circ} \mathrm{C}$ and photoperiod of 12:12h (light: dark).

In both experiment germination was recorded twice daily at higher temperatures $\left(>20^{\circ} \mathrm{C}\right)$ and lower PEG solutions $(>-0.38 \mathrm{MPa})$ and daily at lower temperatures $\left(<20^{\circ} \mathrm{C}\right)$ and higher PEG solutions $(<-0.38 \mathrm{MPa})$. Germinated seeds were removed from each Petri dish. The seeds were defined as germinated if the radicle was $>1 \mathrm{~mm}$, in both experiments.

\section{Statistical procedures}

Mean values of germination rate at different temperatures and water potentials data from experiment were subjected to ANOVA in SAS 8.0 (21). Fisher's protected LSD $(\alpha \leq 0.05)$ was used to separate means.

Data set of final germination at different constant temperatures and different concentrations of PEG solutions was used to create germination time course for estimation of time necessary for $50 \%$ seeds to germinate $\left(t_{50}\right)$. In order to observe difference in the speed of cumulative germination between studied temperatures statistical difference was estimated using analysis of variance. The germination time course to determinate $t_{50}$ was analysed using a logistic function in the Bioassay97 program (22) and then transferred into germination rate or reciprocal of time to $50 \%$ of germination. Germination linear regression line was created according to bootstrap method
(23). The base temperature and base water potential were estimated as the intercept of the regression line with the temperature or water potential axis $(12,24)$. The bootstrap distribution of the estimated base temperature and base water potential was used to determine $95 \%$ confidence interval. Values of base temperature and water potential of the Croatian ecotypes of velvetleaf were then compared to the Italian ecotype, according to the criterion of $95 \%$ confidence intervals overlapping. If did not overlap, they were considered statistically different $(\mathrm{P}=0.05)$, as already adopted in similar studies (25).

\section{RESULTS AND DISCUSSION}

\section{Base temperature}

Final germination rate of $A$. theophrasti was above 50\% at each studied temperature and the highest germination was observed at 16 and $24^{\circ} \mathrm{C}$ with an average of 79.0 and $77.0 \%$, respectively (data not shown). Although viability tests were not performed, final percentage of germination suggests that the dormancy was not fully broken. Several authors reported optimum temperature for germination of velvetleaf around $24^{\circ} \mathrm{C}(26)$ or between 24 to $30^{\circ} \mathrm{C}$ (27). However, all temperatures above $35^{\circ} \mathrm{C}(27)$ or $45^{\circ} \mathrm{C}$ (26) could lead to declined germination.

Cumulative germination was recorded for all studied temperatures described at germination graphs (Figure 1). The relationship between temperature and seed germination is described as a two-parameter logistic function for all temperatures regimes. Observed germination at different temperatures for all three replicates are shown as the black dots while solid line represents the predicted value determinate from the logistic function.

The graphs shows typical S-shaped behaviour with initial lag phase (onset) decreased with increasing temperature. As expected, shortest onset (ED 10) occurred at the temperature of 28,20 and $16^{\circ} \mathrm{C}$ with no significant difference between. The longest onset was observed at lowest temperature $\left(4^{\circ} \mathrm{C}\right)$ where even 31 days were needed for seeds to germinate (Table 1).

Using cumulative germination curve, the information about the time needed for $50 \%$ seed to germinated $\left(t_{50}\right)$ was obtained as a crucial step in the determination of base temperature (Table 1). As expected, velvetleaf germination speed varied at the different temperatures increasing the days required for $50 \%$ germination significantly at temperatures $<20^{\circ} \mathrm{C}$. Fastest germination was achieved at temperatures $>20^{\circ} \mathrm{C}$ with about 4 days needed to complete $50 \%$ of germination. The highest temperatures $\left(28^{\circ} \mathrm{C}, 24^{\circ} \mathrm{C}\right.$ and $\left.20^{\circ} \mathrm{C}\right)$ were not significantly different between $\mathrm{t}_{50}$. Lowering the temperatures germination began to slow. At the lowest temperature $\left(4^{\circ} \mathrm{C}\right)$ seeds needed almost 42 days to achieve $50 \%$ germination which is more than 11-fold lower compared to temperatures $>20^{\circ} \mathrm{C}$. 

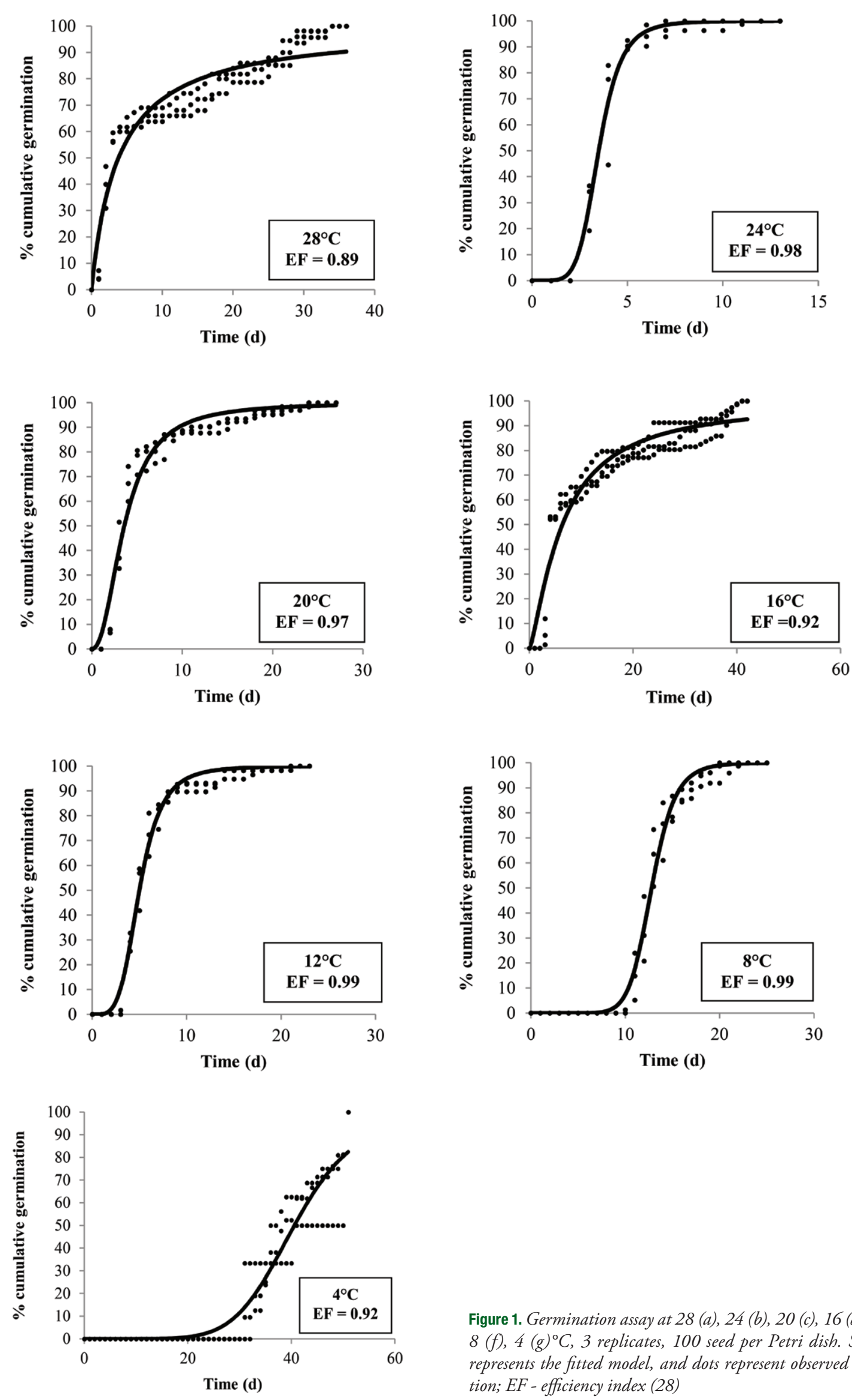

Figure 1. Germination assay at 28 (a), 24 (b), 20 (c), 16 (d), 12 (e), $8(f), 4(g)^{\circ} \mathrm{C}, 3$ replicates, 100 seed per Petri dish. Solid line represents the fitted model, and dots represent observed germination; EF-efficiency index (28) 


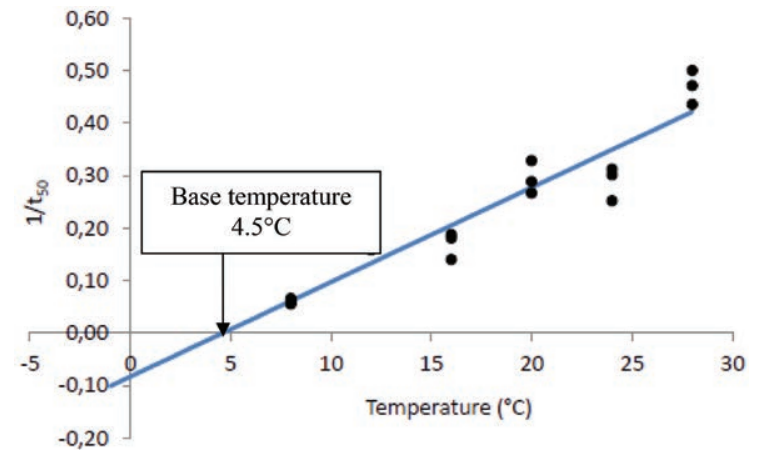

Figure 2. The solid line represents the linear regression line $(y=$ $\left.0,018 x-0,0826, R^{2}=0,90\right)$ and the points are the calculated germination rate $\left(1 / t_{50}\right)$

Linear regression across all temperatures showed increasing germination rate by increasing the incubation temperature following a linear trend (Figure 2). The accuracy of the linear estimation is high with an $\mathrm{R}^{2}$ of 0.90 .

Intercept between linear regression line and temperature axis points value, estimated velvetleaf base temperature of $4.5^{\circ} \mathrm{C}$. Velvetleaf base temperature determinate in this study is consistent to those found in literature, closest to those estimated in Italy, Portugal and Spain. Using the same "x-intercept" method (29) for Italian velvetleaf ecotype base temperature is $3.9^{\circ} \mathrm{C}$ (12), for Portugal ecotype 3.4 to $4.8^{\circ} \mathrm{C}$, while Spain ecotype of velvetleaf had slightly higher temperature threshold from 4.4 to $5.0^{\circ} \mathrm{C}(19)$. Although the lots deriving from the Spanish population were characterised by higher base temperatures at all cultivation sites, these differences were not significant according to the criteria of the overlap of confidence intervals (19). Similar value was also determinate for Iran ecotype of $5.0^{\circ} \mathrm{C}(20)$. Moreover, within the same country, base temperature was tested for different ecotypes. For example, in Italy, for Padua and Pisa velvetleaf ecotypes similar base temperature was estimated, 3.9 and $4.4^{\circ} \mathrm{C}$, respectively (12). On the contrary, in central Spain different value of $6.8^{\circ} \mathrm{C}$ in non-chilled seeds and $7.2{ }^{\circ} \mathrm{C}$ in chilled seeds were reported (18). The highest base temperature of $8.0^{\circ} \mathrm{C}$ value was estimated in Iowa (26).

\section{Base water potential}

Final germination of velvetleaf seed significantly varied with different osmotic potential of the solution. With the increasing of water stress final germination was slightly decreasing to the point where no germination occurs. The greatest germination rate $(77.3 \%)$ was achieved at 0.00 $\mathrm{MPa}$ (deionized water) and was not significantly different to $-0.05 \mathrm{MPa}$ solutions (72.0\%). Germination ceased at 0.80 and $-1.00 \mathrm{MPa}$ (data not shown). Similar data are reported in the literature by different authors. For example, Illinois population of velvetleaf achieved to germinate in the range of -0.10 to $-0.90 \mathrm{MPa}$, although the germination was decreased rapidly with decreasing potential from 0.00 $\mathrm{MPa}$ (30) In the same research, velvetleaf was described as species more tolerant to water stress when compared to another researched weed species such as Ambrosia artemisiifolia L. which completely stopped germination at $-0.60 \mathrm{MPa}$.

The cumulative germination curves for all studied water potential were fitted to a two-parameter logistic function with EF always higher than 0.88 .

The lower water potential i.e. higher osmotic solution lengthened the time taken for seeds to germinate (Figure 3). The highest germination lag (ED 10) occurs from 0.00 $\mathrm{MPa}$ and $-0.25 \mathrm{MPa}$ (Table 1), while decreasing of onset is followed by increasing of the water potential level. As

Table 1. Speed of germination presented through the days required for $10 \%$ and $50 \%$ of germination rate at different incubated temperatures and water potential levels

\begin{tabular}{|c|c|c|c|c|c|c|c|c|c|}
\hline $\begin{array}{c}\text { Temperature } \\
\left({ }^{\circ} \mathrm{C}\right)\end{array}$ & $\mathrm{ED} 10^{\mathrm{a}}$ & $\mathrm{SE}^{\mathrm{b}}$ & $\operatorname{ED~} 50^{a}$ & $\mathrm{SE}^{\mathrm{b}}$ & $\begin{array}{c}\text { Water } \\
\text { potential levels }(\mathrm{MPa})\end{array}$ & $\mathrm{ED} 10^{\mathrm{a}}$ & $\mathrm{SE}^{\mathrm{b}}$ & $\mathrm{ED} 50^{\mathrm{a}}$ & $\mathrm{SE}^{\mathrm{b}}$ \\
\hline 28 & $0.43 \mathrm{a}$ & 0.12 & $3.83 \mathrm{a}$ & 0.41 & 0.00 & $0.86 \mathrm{a}$ & 0.08 & $2.56 \mathrm{a}$ & 0.12 \\
\hline 24 & $2.41 \mathrm{~b} \mathrm{c}$ & 0.08 & $3.52 \mathrm{a}$ & 0.05 & -0.05 & $1.63 \mathrm{a}$ & 0.10 & $3.12 \mathrm{a}$ & 0.08 \\
\hline 20 & $1.37 \mathrm{ab}$ & 0.14 & $3.60 \mathrm{a}$ & 0.16 & -0.10 & $1.19 \mathrm{a}$ & 0.16 & $4.77 \mathrm{a}$ & 0.27 \\
\hline 16 & $1.25 \mathrm{a}$ & 0.20 & $6.39 \mathrm{~b}$ & 0.40 & -0.25 & $2.19 \mathrm{a}$ & 0.13 & $4.49 \mathrm{a}$ & 0.11 \\
\hline 12 & $3.23 \mathrm{c}$ & 0.13 & $5.01 \mathrm{~b}$ & 0.09 & -0.38 & $4.81 \mathrm{~b}$ & 0.24 & $10.62 \mathrm{~b}$ & 0.26 \\
\hline 8 & $10.42 \mathrm{~d}$ & 0.17 & $12.90 \mathrm{c}$ & 0.14 & -0.50 & $6.26 \mathrm{~b}$ & 0.28 & $9.66 \mathrm{~b}$ & 0.23 \\
\hline 4 & 30.38 e & 0.75 & $41.95 \mathrm{~d}$ & 0.45 & - & - & - & - & - \\
\hline Fisher's LSD & 1.31 & - & 1.81 & - & - & 2.26 & - & 3.48 & - \\
\hline
\end{tabular}

a values within a column followed by the same letter are not significantly different at $\mathrm{P} \geq 0.05$

b SE; standard error 

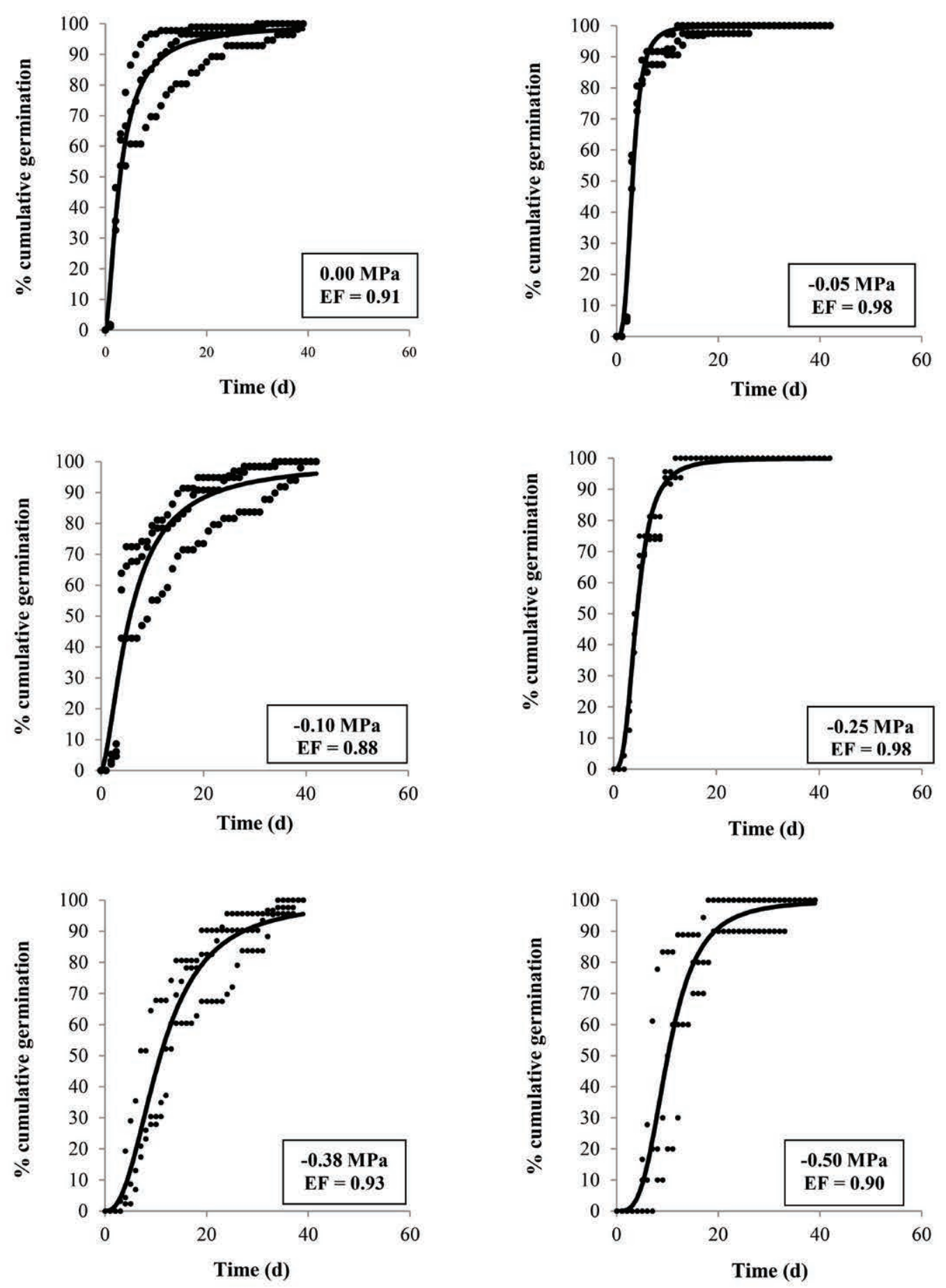

Figure 3. Germination assay at $0.00(\mathrm{a}),-0.05(\mathrm{~b}),-0.10(\mathrm{c}),-0.25(\mathrm{~d}),-0.38(e),-0.50(f) \mathrm{MPa}, 3$ replicates, 100 seed per Petri dish. Solid line represents the fitted model, and dots represent observed germination; EF-efficiency index (28)

confirmed in the literature in field conditions, moisture stress decreases initial germination of velvetleaf which is consequently followed by slower root and shoots elongation (31).

There was no significant difference in time necessary for $50 \%$ seeds to germinate at water potential from 0.00 to $-0.25 \mathrm{MPa}$, with an average of 4.9 days (Table 1). Sta- tistical difference occurred at water potential $<-0.38$ $\mathrm{MPa}$, where it took approximately 10 days for seeds to achieve $50 \%$ germination.

Estimated base water potential of velvetleaf is -0.67 $\mathrm{MPa}$ (Figure 4) which shows high sensitivity of this weed species to water stress. Although, there are small amount of literature data of base water potential for velvetleaf, 


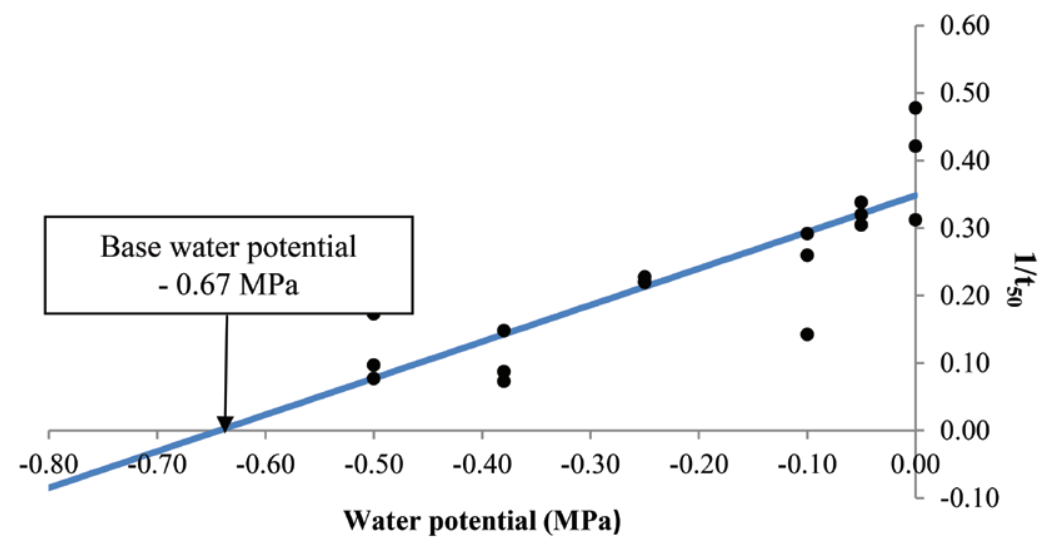

Figure 4. The solid line represents the linear regression line $\left(y=0.3485 x+0.5421, R^{2}=0.76\right)$ and the points are the calculated germination rate $\left(1 / t_{50}\right)$

available values are not quite different among different population. The recorded base water potential for Spain population is at the range from -0.64 to $-0.73 \mathrm{MPa}$ (18), similar with Italian ecotype of $-0.78 \mathrm{MPa}$ (12) and Iran ecotype of $-0.60 \mathrm{MPa}(20)$. It is interesting to observe that the WeedCast predictive emergence model applied within the north-central region of the United States and neighbouring Canada (32) uses the highest base water potential of $-0.15 \mathrm{MPa}$.

\section{Comparison of biological parameters among Croatian and Italian ecotypes}

The main aim of the research was to determine if there is a difference in biological parameters between Croatian and Italian ecotype of velvetleaf in order to transfer Italian predictive weed emergence model to Croatia. According to the criteria of the overlap of $95 \%$ of confidence level, Croatian $\left(4.5^{\circ} \mathrm{C}\right)$ and Italian $\left(3.9^{\circ} \mathrm{C}\right)$ ecotype showed statistical similar values (Figure 5). Similarly, base water potential between Croatian $(-0.67 \mathrm{MPa})$ and Italian $(-0.78 \mathrm{MPa})$ ecotypes were also not significantly different (Figure 5).

For this weed species the literature does not report a great variability in biological parameters as is for example for weed species Echinochloa crus-galli L. (P. Beauv.) with base temperature estimated in the wide range from 5.0 to $13.8^{\circ} \mathrm{C}(2,20)$ which indicates existence of the high diversities in this population worldwide. However, the differences among velvetleaf ecotypes of different geographic origins still exist. Variation in temperature threshold are explained as the inter-population variability among different geographic origin affected by various climatic conditions under which mother plant is maturating. In the literature this phenomenon is described with the term „preconditioning“ (33). Often, for weed species germination requirements are conditioned with differences in dormancy. For instance, in velvetleaf case physical dormancy is caused by hardness of seed (34) which can be less or more developed depending on climatic area (35). Another factor which defines variations within the same species is caused due to genetic characteristic of the seeds. Sexual reproduction and exchanging of genetic material gives the opportunity for a wide spread weed to adjust current environment and therefore to allocate species with most suitable features in the certain environment (33). Hence, importance of the estimation of biological parameters for local ecotype is crucial.

It is considerable to point out that this biological parameter has never been estimated before for any of Croatian weed species. Since results of our study showed no difference in velvetleaf biological parameters compared with ecotype used is AlertInf model, here is open ability
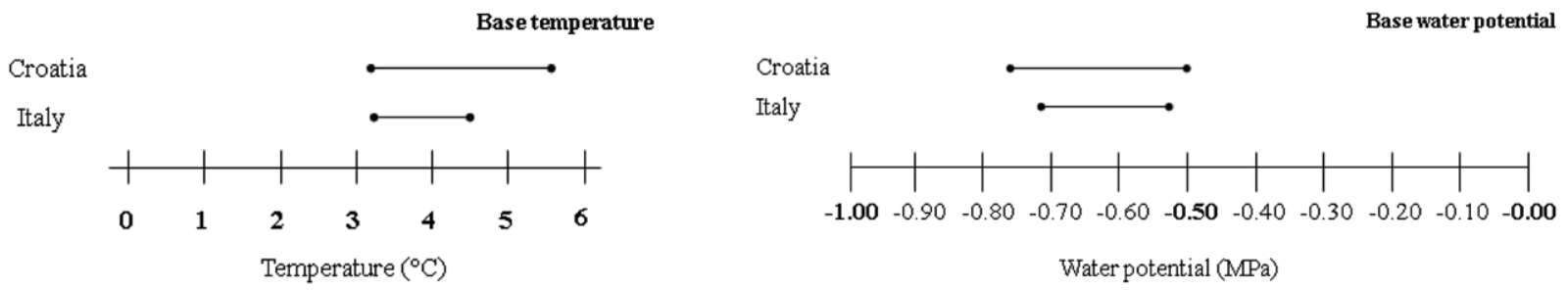

Figure 5. Comparison of base temperature (left) and base water potential (right) between estimated Croatian and Italian ecotype of velvetleaf determined by Masin et al (22) 
to implement this predictive weed emergence model in Croatia for this species without additional adjustment.

Before implementation it is necessary to valid this estimated parameters in the field conditions where germination is influenced by other factors not included in this research. It is well know that temperature and water potential are not the only factors that influence germination in the field. The benefit of velvetleaf characteristic is the fact that its germination is not influenced by light, like some other weed species, for example Veronica hederifolia L. (29). In addition to that, germination is not dependent on different $\mathrm{pH}$ of soil like it is for Echinochloa crus-galli L. (P. Beauv) which shows sensitivity to acid soils decreasing significantly germination (20). On the contrary, the oxygen levels in different soil type can affect the germination rate of velvetleaf, and with decreasing of the oxygen level in the soil, germination of velvetleaf is inhibited (36). Furthermore, velvetleaf germination could be decreased in high-salinity soil at concentration of $225 \mathrm{mM} \mathrm{NaCl}$. Also, uptake of water by seeds at the different stress levels is increased by the temperature (20), which was not indeed included in our study, where only one temperature was used at different water stress levels.

From all above mentioned it is clear that velvetleaf can germinate under various environmental conditions, although in some cases germination could be reduced. Thus, emergence studies at the field conditions and at different soil type conditions should be performed for this weed species in order to re-evaluate laboratory estimated biological parameters. The first obtained results are quiet positive which encourages further development of the model AlertInf and future studies to test its transferability to Croatia not only for velvetleaf but for other problematic weeds in Croatia.

\section{CONCLUSIONS}

Following the aim of the experiment, i) estimation of biological parameters of velvetleaf and ii) comparison of Croatian and Italian biological parameters, was accomplished by determining base temperature of Croatian ecotype at $4.5^{\circ} \mathrm{C}$ and base water potential at $-0.67 \mathrm{MPa}$ with no significant difference compared to Italian ecotype, according to the criteria of the overlap of $95 \%$ of confidence level. Therefore, the possibility of implementation of predictive weed emergence model AlertInf for velvetleaf is for now possible. However, to make this statement for sure, it is important to conduct field experiments throughout the several years to see if the laboratory estimated values are valid in the field conditions.

Since, lacking of water can result in absence of germination, although there are optimal temperatures for germination in the field. Combination of two parameters $\left(\mathrm{T}_{\mathrm{b}}\right.$ i $\left.\Psi_{\mathrm{b}}\right)$ in the future experiments will provide more accurate information about the time of emergence in the field.
Further experiments should be also focused on estimation of biological parameters for other problematic weed species in row crops. Moreover, by including more weed species in predictive model, weed control would be more efficient and useful in summer crops were mixed weed populations usually occur.

\section{REFERENCES}

1. ZANIN, G., SATTIN, M 1988 Threshold level and seed production of velvetleaf (Abutilón theophrasti Medicus) in maize. Weed Research 28: 347-352.

https://doi.org/10.1111/j.1365-3180.1988.tb00813.x

2. STEINMAUS, S J, NORRIS, R F 2002 Growth analysis and canopy architecture of velvetleaf grown under light conditions representative of irrigated Mediterranean-type agroecosystems. Weed Science 50:42-53.

https://doi.org/10.1614/0043-1745(2002)050[0042:GAACAO]2.0. $\mathrm{CO} ; 2$

3. BASKIN, J M, BASKIN, C C 1989 Physiology of dormancy and germination in relation to seed bank ecology. In M. A. Leck, V. T. Parker and R. L. Simpson, eds. Ecology of Soil Seed Banks. New York: Academic Press, pp. 53-66.

https://doi.org/10.1016/B978-0-12-440405-2.50009-9

4. BENVENUTI, S, MACCHIA, M, MIELE, S 2001 Quantitative analysis of emergence of seedlings from buried weed seeds with increasing soil depth, Weed Science, 49(4), pp. 528-535. https://doi.org/10.1614/0043-1745(2001)049[0528:QAOEOS]2.0. $\mathrm{CO} ; 2$

5. PLODINEC, M, ŠĆEPANOVIĆ, M, BARIĆ, K, JAREŠ, D 2015 Inter-populacijska varijabilnost u nicanju korovne vrste Abutilon theophrasti Med., Agronomski glasnik. 63, 1-2; 23-40.

6. EGLYE, G H, WILLIAMS, R D 1991 Emergence periodicity of six summer annual weed species. Weed Science 4.595-600.

7. JURSÍK M, SOUKUP J, VENCLOVÁ V, HOLEC J 2011 POST Herbicide combinations for velvetleaf (Abutilon theophrasti) control in sugarbeet. Weed Technology, 25:14-18. https://doi.org/10.1614/WT-D-10-00059.1

8. GRUNDY, A C 2003 Predicting weed emergence: a review of approaches and future challenges. Weed Research, 43: 1 - 11. https://doi.org/10.1046/j.1365-3180.2003.00317.x

9. WEEDCAST VERSION 4.0. Technical documentation. Available: https://www.ars.usda.gov/research/software/, accessed 08 March 2017.

10. BATTLA, D, BENECH-ARNOLD, R L 2007 Predicting changes in dormancy level in weed seed soil banks: implications for weed management. Crop Prot. 26:189-197. https://doi.org/10.1016/j.cropro.2005.07.014

11. STARKE, R J, K A RENNER 1996. Velvetleaf (Abutilon theophrasti) and sugarbeet (Beta vulgaris) response to triflusulfuron and desmedipham plus phenmedipham. Weed Technology. 10:121 -126. https://doi.org/10.1017/S0890037X00045814

12. MASIN R, LODDO D, BENVENUTI S, ZUIN M C, MACCHIA, M, ZANIN G 2010 Temperature and water potential as parameters for modeling weed emergence in central-northern Italy. Weed Science, 58:216-222. https://doi.org/10.1614/WS-D-09-00066.1

13. ROMAN, E S, MURPHY, S D, SWANTON, C, J, 2000 Simulation of Chenopodium album seedling emergence. Weed Science, 48:217-224.

https://doi.org/10.1614/0043-1745(2000)048[0217:SOCASE]2.0. $\mathrm{CO} ; 2$ 
14. MARTINSON, K, DURGAN, B, FORCELLA, F, WIERSMA, J, SPOKAS, K ARCHER, D 2007 An emergence model for wild oat (Avena fatua). Weed Science, 55: 584-591. https://doi.org/10.1614/WS-07-059.1

15. IZQUIERDO, J, GONZÁLEZ-ANDÚJAR J, BASTIDA F, LEZAÚN J A, SÁNCHEZ-DEL M J 2009 A thermal time to predict corn poppy (Papaver rhoeas) emergence in cereal fields. Weed Sci. 57: 660 - 664. https://doi.org/10.1614/WS-09-043.1

16. GONZALEZ-ANDUJAR J L, CHANTRE G R, MORVILLO C, BLANCO A M FORCELLA F 2016 Predicting field weed emergence with empirical models and soft computing techniques. Weed Research 56, 415-423. https://doi.org/10.1111/wre.12223

17. MCGIFFEN M, SPOKAS K, FORCELLA F, ARCHER D, POPPE, S, FIGUEROA R 2008 Emergence prediction of common groundsel (Senecio vulgaris). Weed Science 56, 58-65. https://doi.org/10.1614/WS-07-060.1

18. DORADO, J, FERNANDEZ-QUINTANILLA C, GRUNDY A C 2009 Germination patterns in naturally chilled and non-chilled seeds of fierce thornapple (Datura ferox) and velvetleaf (Abutilon theophrasti). Weed Science, 57:155-162. https://doi.org/10.1614/WS-08-122.1

19. LODDO D, SOUSA E, MASIN R, CALHA I, ZANIN G, FERNANDEZ-QUINTANILLA C, DORADO J 2013 Estimation and Comparison of Base Temperatures for Germination of European Populations of Velvetleaf (Abutilon theophrasti) and Jimsonweed (Datura stramonium). Weed Science 61:443-451. https://doi.org/10.1614/WS-D-12-00162.1

20. SADEGHLOO, A, ASGHATI, J, GHADERI-FAR, F 2013 Seed germination and seedling emergence of velvetleaf (Abutilon theophrasti) and barnyardgrass (Echinochloa crus-galli). Planta Daninha, Viçosa-MG, v. 31, n. 2, p. 259-266. https://doi.org/10.1590/S0100-83582013000200003

21. SAS INSTITUTE 1997 SAS/STAT Software: Changes and enhancements through Rel. 6.12. SAS Inst., Cary, NC.

22. ONOFRI, A 2001 BIOASSAY97: A New EXCEL tVBA Macro to Perform Statistical Analyses on Pesticide Dose-Response Data http://www.agr.unipg.it/disaprov/bioassay97/bioassay97.htm; last accessed 10 January 2017.

23. EFRON, B 1979 Bootstrap methods: another look at the jackknife. Ann. Stat. 7:1-26. https://doi.org/10.1214/aos/1176344552

24. MASIN R, ZUIN M C, ARCHER, D W, ZANIN, G 2005 WeedTurf: a predictive model to aid control of annual summer weeds in turf. Weed Science, 53:193-201.

https://doi.org/10.1614/WS-04-066R1

25. LODDO, D, MASIN R, OTTO S, ZANIN G 2012 Estimation of base temperature for Sorghum halepense rhizome sprouting. Weed Research 52:42-49. https://doi.org/10.1111/j.1365-3180.2011.00886.x

26. LEON R G, KNAPP A D, OWEN, M D K 2004 Effect of temperature on the germination of common waterhemp (Amaranthus tuberculatus), giant foxtail (Setaria faberi), and velvetleaf (Abutilon theophrasti). Weed Science 52, 67-73.

https://doi.org/10.1614/P2002-172

27. HOROWITZ, M, TAYLORSON, R B 1984 Hardseededness and germinability of velvetleaf (Abutilon theophrasti) as affected by temperature and moisture. Weed Science 32: 111 - 115.

28. LOAGUE, K, GREEN, R E 1991 Statistical and graphical methods for evaluating solute transport models: overview and application. J. Cont. Hydrol. 7:51-73. https://doi.org/10.1016/0169-7722(91)90038-3

29. GUILLEMIN, J P, GARDARIN, A, GRANGER, S, REIBEL, C, MUNIER-JOLAIN, N, COLBACH, N 2013 Assessing potential germination period of weeds with base temperatures and base water potential, Weed Research 53: 76 - 87 . https://doi.org/10.1111/wre.12000

30. RAYNAL, D, J, BAZZAZ, F, A 1973 Establishment of early successional plant populations on forest and prairie soil. Ecol. 54: 1335 - 1341. https://doi.org/10.2307/1934196

31. BECKER, R L 1979 Weed seedling emergence under osmotic stress. Abstract. Proc. North Cent., Weed Control Conf. 34: 45.

32. ARCHER, D W, FORCELLA F, EKLUND J J, AND J GUNSOLUS 2001 WeedCast Version 2.0. www.morris.ars.usda.gov

33. BASKIN, C C, BASKIN, J M 2001 Seed ecology, biogeography, and evolution of dormancy and germination. School of Biological Sciences, University of Kentucky, Academic press: 181 - 219.

34. WARWICK, S I, BLACK, L D 1988. The biology of Canadian weeds. 90. Abutilon theophrasti. Canadian Journal of Plant Science 68 : 1069-1085. https://doi.org/10.4141/cjps88-127

35. CARDINA, J, SPARROW, DH 1997 Temporal Changes in Velvetleaf (Abutilon theophrasti) Seed Dormancy, Weed Science, 45: 61-66.

36. HOLM, R E 1972 Volatile metabolites controlling germination in buried weed seeds. Plant Physiol. 50: 293 - 297. https://doi.org/10.1104/pp.50.2.293 